\title{
MARKET ANOMALY ANALYSIS: THE DAY OF THE WEEK EFFECT, JANUARY EFFECT, ROGALSKY EFFECT AND WEEK- FOUR EFFECT TESTING IN INDONESIA STOCK EXCHANGE (CASE STUDY ON COMPANIES LISTED IN LQ45 INDEX IN 2013- 2017)
}

\author{
Wendra Bagaskara ${ }^{1}$, Khairunnisa ${ }^{1}$ \\ ${ }^{1}$ Telkom University Bandung, Indonesia \\ Email : wendrabagaskara@telkomuniversity.ac.id \\ Email : khairunnisa@telkomuniversity.ac.id
}

\begin{tabular}{|c|c|}
\hline INFO ARTIKEL & ABSTRAK/ABSTRACK \\
\hline $\begin{array}{l}\text { Histori Artikel : } \\
\text { Tgl. Masuk : } 12 \text { Maret } 2019 \\
\text { Tgl. Diterima : } 22 \text { Maret } 2019 \\
\text { Tersedia Online : } 29 \text { Maret } \\
2019 \\
\text { Keywords: } \\
\text { Market Anomalies, The Day of } \\
\text { The Week Effect, January } \\
\text { Effect, Rogalsky Effect, Week } \\
\text { Four Effect }\end{array}$ & $\begin{array}{l}\text { Financial theory explained that there are four types of } \\
\text { anomalies such as firm anomaly, seasonal anomaly, event } \\
\text { anomaly, and accounting anomaly. Seasonal anomalies are } \\
\text { divided into several parts such as The Day of The Week } \\
\text { Effect, the January Effect, Rogalsky Effect, and Week-Four } \\
\text { Effect. The results of research in Indonesia show mixed } \\
\text { results related to this anomaly. } \\
\text { The purpose of this research is to test wether The Day of } \\
\text { The Week Effect, January Effect, Rogalsky Effect, and } \\
\text { Week-Four Effec market anomalyt occurred on the } \\
\text { Indonesia Stock Exchange. This research is a study that } \\
\text { uses quantitative research methods with the purpose of } \\
\text { descriptive-verification. The unit of analysis of this research } \\
\text { is the companies that registered consistently in the LQ45 } \\
\text { index for the period } 2013-2017 \text { using purposive sampling } \\
\text { technique. This study used } 37 \text { research samples for } 5 \text { years } \\
\text { of research and used a different test analysis with SPSS } \\
\text { Statistics } 25 \text {. } \\
\text { The results showed that there was an anomaly of The } \\
\text { Day of The Week Effect on the Indonesia Stock Exchange } \\
\text { and there was no anomaly in the January Effect, Rogalsky } \\
\text { Effect, and Week-Four Effect on the Indonesia Stock } \\
\text { Exchange. }\end{array}$ \\
\hline
\end{tabular}

\section{PENDAHULUAN}

Dalam teori keuangan dijelaskan bahwa terdapat sedikitnya empat jenis dalam anomali pasar yaitu anomali perusahaan (Firm Anomalies), anomali musiman (Seasonal Anomalies), anomali peristiwa (Event Anomalies), dan anomali akuntansi (Accounting Anomalies). Salah satu dari klasifikasi anomali pasar adalah anomali musiman (seasonal anomalies) dimana terjadi anomali pada harga saham yang terjadi pada hari-hari atau waktuwaktu tertentu. Dalam anomali musiman ini terdapat lagi macam-macamnya seperti The Day of The Week Effect,
January Effect, Week-Four Effect, dan Rogalsky Effect. The Day of The Week Effect merupakan sebuah anomali dimana return sekuritas terendah terjadi pada hari Senin. January Effect merupakan sebuah anomali dimana return sekuritas cenderung naik pada bulan Januari. Week-Four Effect merupakan sebuah anomali dimana return sekuritas terendah terjadi pada hari Senin pada minggu ke-empat dan Rogalsky Effect merupakan sebuah anomali gabungan antara January Effect dengan The Day of The Week Effect dimana return saham pada hari senin 
yang cenderung negatif akan hilang pada bulan Januari.

Di Indonesia, penelitian terhadap anomali pasar seasonal menunjukkan hasil yang beraneka ragam. Menurut hasil penelitian yang dilakukan oleh Cahyaningdyah (2017) yang meneliti pada Bursa Efek Indonesia periode 20072015 menunjukkan bahwa ditemukan beberapa perbedaan pengaruh hari perdagangan terhadap return saham dimana ditemukan return saham negatif pada hari Senin (Monday Effect) dan laba terbesar terjadi pada hari Jumat (Weekend Effect). Sementara itu, fenomena Week four effect tidak ditemukan dalam penelitian. Sama halnya dengan penelitian yang dilakukan oleh Indrasari \& Tahar (2016) yang melakukan peneliti terhadap pengaruh hari perdagangan terhadap return saham di Bursa Efek Jakarta menyatakan bahwa return saham pada hari perdagangan Senin lebih rendah dari return pasar dan untuk hari perdagangan Selasa, Rabu, Kamis, dan Jumat menunjukkan bahwa return saham berada diatas return pasar. Hasil penelitian tersebut sangat bertolak belakang dengan hasil penelitian yang dilakukan oleh Putra (2016) yang menggunakan metode pengumpulan data dengan dokumentasi data harga saham harian secara time series periode Januari 2014 - Desember 2014 di Bursa Efek Indonesia. Hasil dari penelitiannya mengatakan bahwa rata-rata return untuk hari Senin menunjukkan hasil positif, dengan demikian tidak terjadi Monday Effect di Bursa Efek Indonesia. Sedangkan, rata-rata return hari Jumat juga bernilai positif dengan demikian terjadi Weekend Effect di Bursa Efek Indonesia. Pada penelitian Wihandaru dalam Rita (2009) menunjukkan bahwa tidak adanya Monday Effect pada return pasar IHSG, namun ditemukan dalam LQ45. Sama seperti penelitian yang dilakukan oleh Suwarni dan Primawurti dalam Rita yang menunjukkan bahwa pada return pasar IHSG tidak ditemukan adanya Monday effect. Dalam penelitian yang dilakukan oleh Rita sendiri menunjukkan bahwa Monday Effect tidak hanya terjadi dalam dua minggu terakhir, namun Monday Effect juga terjadi dalam tiga minggu pertama dan juga menemukan bahwa adanya Rogalsky Effect yang hadir pada bulan Januari.

\section{KERANGKA TEORITIS DAN PENGEMBANGAN HIPOTESIS}

\section{Anomali Pasar}

Menurut Jones (2014) anomali pasar merupakan sekumpulan rencana dan tehnik yang saling bertolak belakang dengan teori pasar modal yang efisien. Anomali pasar akan menyebabkan hasil yang sangat berlawanan dengan konsep pasar modal dan penyebab anomali pasar ini masih menjadi sebuah pertanyaan besar bagi para ahli keuangan. Dalam anomali kita akan menemukan sesuatu yang tidak seharusnya kita temukan apabila pasar efisien benar benar ada.

Pengambilan keputusan yang dibantu dengan anomali pasar ini harus dilakukan dengan hati-hati. Anomali pasar tidak menjamin para investor akan menentukan keputusan investasi yang benar karena hasil pengujian empiris terkait anomali pasar ini bukan merupakan strategi investasi sesungguhnya

1) Hari Perdagangan (The Day of The Week Effect)

Hari Senin sampai dengan Hari Jumat merupakan hari dimana perdagangan dilakukan. Menurut Damodaran (1996) dalam hal ini akan terjadi perbedaan return yang signifikan setiap harinya mulai dari hari Senin hingga hari Jumat

2) Bulan Januari (January Effect)

January Effect merupakan fenomena dimana harga saham 
memiliki kecenderungan untuk naik pada bulan Januari. $\mathrm{Hal}$ ini menunjukkan bahwa rata-rata return bulan Januari akan cenderung lebih tinggi jika dibandingkan dengan ratarata return pada bulan non Januari.

3) Efek Rogalsky (Rogalsky Effect)

Penamaan efek Rogalsky ini berasal dari peneliti yang bernama Rogalsky yang menemukan sebuah hubungan yang terjadi antara January Effect dengan The Day of The Week Effect. Rogalsky dalam Cahyaningdyah (2017) menyatakan bahwa terdapat hubungan antara fenomena January Effect dengan The Day of The Week Effect dimana return akan cenderung negatif pada hari senin akan hilang pada bulan Januari

4) Minggu Keempat (Week-Four Effect)

Week-Four Effect merupakan sebuah fenomena yang menyatakan bahwa fenomena Monday Effect terjadi hanya pada akhir pekan setiap bulannya. Artinya keadaan return hari Senin yang cenderung lebih rendah daripada return pada hari non Senin hanya terjadi pada akhir pekan di setiap bulannya.

\section{Imbal Hasil (Return)}

Return adalah sebuah keadaan dimana investor mendapatkan keuntungan atas tindakan investasi yang dilakukannya (Fahmi, 2014). Return dapat berbentuk return realisasi (Realized Return) atau return ekspektasi (Expected Return). Return realisasi adalah return yang sudah terjadi dan dihitung menggunakan data masa lalu. Sementara return ekspektasi adalah return yang diharapkan akan didapatkan oleh investor pada masa yang akan datang. Dalam penelitian ini digunakan return dengan perhitungan sebagai berikut:

$$
R_{i}=\frac{P_{t}-P_{t-1}+D_{t}}{P_{t-1}}
$$

$\mathrm{R}=$ = Return Saham

$\mathrm{P}_{\mathrm{t}} \quad=$ Harga Saham pada Periode $\mathrm{t}$

$\mathrm{P}_{(\mathrm{t}-1)} \quad=$ Harga Saham pada Periode $\mathrm{t}-1$

$D_{t} \quad=$ Dividen pada Periode $t$

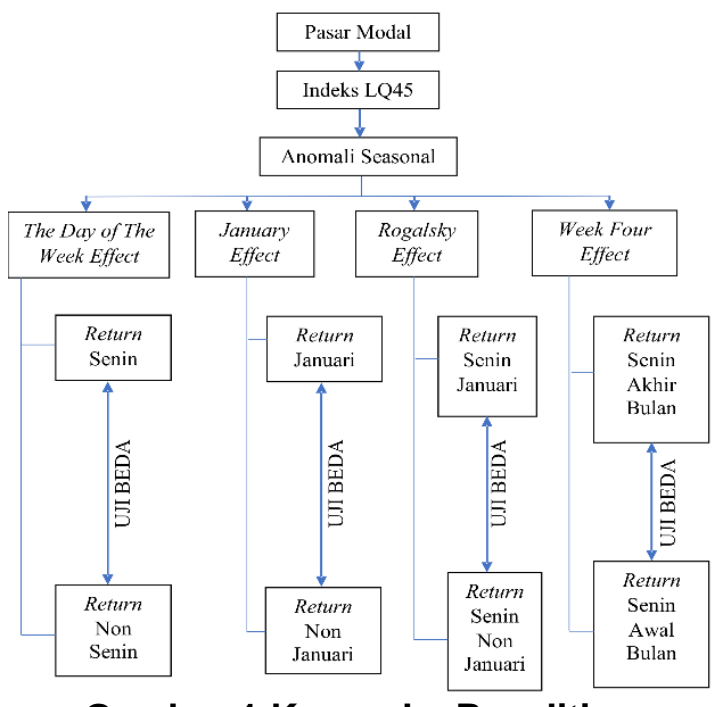

Gambar 1 Kerangka Penelitian

\section{Hipotesis}

Berdasarkan pembahasan pada kerangka penelitian yang telah diuraikan sebelumnya, maka peneliti mengajukan hipotesis sementara sebagai berikut:

$\mathrm{H}_{1}$ : Terdapat perbedaan return yang signifikan antara return hari tertentu dengan return hari-hari perdagangan lainnya pada return saham-saham perusahaan yang ada di Indeks LQ45 (The Day of The Week Effect).

$\mathrm{H}_{2}$ : Terdapat perbedaan return yang signifikan antara return bulan Januari dengan return bulan-bulan lainnya pada return saham-saham perusahaan yang ada di Indeks LQ45 (January Effect).

$\mathrm{H}_{3}$ : Terdapat perbedaan return yang signifikan antara return hari Senin di bulan Januari dengan return hari Senin di bulan-bulan lainnya pada return saham-saham perusahaan yang ada di Indeks LQ45 (Rogalsky Effect).

$\mathrm{H}_{4}$ : Terdapat perbedaan return yang signifikan antara return hari Senin di minggu ke-4 dengan return hari 
Senin di minggu-minggu lainnya pada return saham-saham perusahaan yang ada di Indeks LQ45 (Week-Four Effect).

\section{METODOLOGI PENELITIAN}

Populasi dalam penelitian ini adalah perusahaan yang terdaftar secara konsisten dalam Indeks LQ45. Teknik sampel yang digunakan dalam penelitian ini adalah purposive sampling dengan kriteria konsisten terdaftar dalam Indeks LQ45 dan tidak melakukan Corporate Action. Teknik analisis yang digunakan untuk menganalisis return saham dalam penelitian ini menggunakan analisis statistik deskriptif dan uji beda menggunakan Teknik Kruskall Wallis

Operasional variabel dapat diliihat pada tabel berikut:

Tabel 1

Operasional Variabel

\begin{tabular}{|c|c|c|}
\hline Variabel & Indikator & Skala \\
\hline $\begin{array}{c}\text { Return } \\
\text { Saham }\end{array}$ & $R_{i}=\frac{P_{t}-P_{t-1}+D_{t}}{P_{t-1}}$ & \\
& & Rasio \\
\hline
\end{tabular}

\section{HASIL DAN PEMBAHASAN}

\section{Statistik Deskriptif}

Tabel 2

Hasil Uji Statistik Deskriptif

\begin{tabular}{|l|c|c|c|c|c|}
\hline & Maks & Min & Mean & $\begin{array}{c}\text { Std. } \\
\text { Dev }\end{array}$ & N \\
\hline Senin & 0,3196 & $-0,0742$ & 0,0154 & 0,0715 & 244 \\
\hline Selasa & 0,3352 & $-0,0497$ & 0,0107 & 0,0586 & 248 \\
\hline Rabu & 0,3236 & $-0,0446$ & 0,0144 & 0,0638 & 250 \\
\hline Kamis & 0,3090 & $-0,0551$ & 0,0088 & 0,0502 & 239 \\
\hline Jumat & 0,3067 & $-0,0448$ & 0,0097 & 0,0573 & 244 \\
\hline
\end{tabular}

Sumber: Data yang diolah penulis (2019)

Dari tabel 2 dapat dilihat bahwa rata-rata return pada hari Senin berada pada nilai 0,015450 yang kemudian turun pada hari Selasa menjadi 0,010780. Pada hari rabu rata-rata return meningkat menjadi 0,014404 dan kembali turun pada hari Kamis menjadi 0,008819 yang berakhir pada hari Jumat dengan nilai 0,009773 . Berdasarkan tabel 2 dapat juga kita lihat bahwa nilai mean untuk rata-rata return setiap harinya lebih kecil dari standar deviasi, yang menggambarkan data yang cenderung tidak berkelompok atau heterogen.

\section{The Day of The Week Effect}

Hasil uji Kruskal Wallis menghasilkan nilai sebagai berikut:

Tabel 3

\section{Hasil Pengujian Kruskal Wallis The Day of The Week Effect}

\begin{tabular}{|c|c|c|c|c|}
\hline Return & $\mathrm{N}$ & $\begin{array}{l}\text { Mean } \\
\text { Rank }\end{array}$ & $\begin{array}{l}\text { Asymp. } \\
\text { Sig. }\end{array}$ & Ket. \\
\hline $\begin{array}{l}\text { Senin } \\
\text { Non Senin }\end{array}$ & $\begin{array}{l}244 \\
981\end{array}$ & $\begin{array}{l}579,80 \\
621,26\end{array}$ & 0,136 & Tidak Berbeda \\
\hline $\begin{array}{l}\text { Selasa } \\
\text { Non } \\
\text { Selasa }\end{array}$ & $\begin{array}{l}248 \\
977\end{array}$ & $\begin{array}{l}618,79 \\
611,53\end{array}$ & & Tidak Berbeda \\
\hline $\begin{array}{l}\text { Rabu } \\
\text { Non Rabu }\end{array}$ & $\begin{array}{l}250 \\
975\end{array}$ & $\begin{array}{l}659,73 \\
600,96\end{array}$ & 0 & Berbeda \\
\hline $\begin{array}{l}\text { Kamis } \\
\text { Non } \\
\text { Kamis }\end{array}$ & $\begin{array}{l}239 \\
986\end{array}$ & $\begin{array}{l}617,39 \\
611,94\end{array}$ & & Tidak Berbeda \\
\hline $\begin{array}{l}\text { Jumat } \\
\text { Non } \\
\text { Jumat }\end{array}$ & $\begin{array}{l}244 \\
981\end{array}$ & $\begin{array}{l}584,89 \\
619,99\end{array}$ & 0,165 & Tidak Berbeda \\
\hline
\end{tabular}

Sumber: Output SPSS Statistic 25 (2019)

Pada tabel 2 dapat dilihat bahwa implikasi dari penelitian ini menunjukkan bahwa tidak terjadi perbedaan yang signifikan antara rata-rata return hari Senin dengan hari lainnya namun terjadi perbedaan yang signifikan antara ratarata return hari Rabu dengan hari lainnya di Indeks LQ45. Maka, dapat disimpulkan bahwa ditemukan anomali The Day of The Week Effect pada saham yang terdaftar dalam indeks LQ45 periode 2013-2017 tepatnya pada hari Rabu.

\section{January Effect}

Hasil uji Kruskal Wallis menghasilkan nilai sebagai berikut: 
Tabel 4

Hasil Pengujian Kruskal Wallis January Effect

\begin{tabular}{|c|c|c|c|c|}
\hline Return & $\mathrm{N}$ & $\begin{array}{l}\text { Mean } \\
\text { Rank }\end{array}$ & $\begin{array}{l}\text { Asym } \\
\text { Sig }\end{array}$ & Ket. \\
\hline $\begin{array}{l}\text { Januari } \\
\text { Non } \\
\text { Januari }\end{array}$ & \begin{tabular}{|l|}
103 \\
1122
\end{tabular} & $\begin{array}{l}646,06 \\
610,15\end{array}$ & 0,352 & Tidak Berbeda \\
\hline $\begin{array}{l}\text { Februari } \\
\text { Non } \\
\text { Februari }\end{array}$ & $\begin{array}{l}99 \\
1126\end{array}$ & $\begin{array}{l}682,32 \\
606,90\end{array}$ & 0,042 & Berbeda \\
\hline $\begin{array}{l}\text { Maret } \\
\text { Non Maret }\end{array}$ & $\begin{array}{l}102 \\
1123\end{array}$ & $\begin{array}{l}629,59 \\
613,87\end{array}$ & 0,621 & Tidak Berbeda \\
\hline \begin{tabular}{|l|} 
April \\
Non April
\end{tabular} & $\begin{array}{l}98 \\
1127\end{array}$ & $\begin{array}{l}600,46 \\
614,09\end{array}$ & 0,772 & Tidak Berbeda \\
\hline $\begin{array}{l}\text { Mei } \\
\text { Non Mei }\end{array}$ & $\begin{array}{l}99 \\
1126\end{array}$ & $\begin{array}{l}633,57 \\
611,19\end{array}$ & 0,546 & Tidak Berbeda \\
\hline \begin{tabular}{|l|} 
Juni \\
Non Juni \\
\end{tabular} & $\begin{array}{l}105 \\
1120 \\
\end{array}$ & $\begin{array}{l}581,91 \\
615,91\end{array}$ & 0,346 & Tidak Berbeda \\
\hline $\begin{array}{l}\text { Juli } \\
\text { Non Juli }\end{array}$ & \begin{tabular}{|l}
98 \\
1127
\end{tabular} & $\begin{array}{l}600,39 \\
614,10\end{array}$ & 0,713 & Tidak Berbeda \\
\hline \begin{tabular}{|l|} 
Agustus \\
Non \\
Agustus \\
\end{tabular} & $\begin{array}{l}102 \\
1123\end{array}$ & $\begin{array}{l}593,29 \\
614,79\end{array}$ & 0,557 & Tidak Berbeda \\
\hline $\begin{array}{l}\text { September } \\
\text { Non } \\
\text { September }\end{array}$ & $r$ & $\begin{array}{l}554,61 \\
618,53\end{array}$ & 0,075 & Tidak Berbeda \\
\hline \begin{tabular}{|l|} 
Oktober \\
Non \\
Oktober
\end{tabular} & $\begin{array}{l}108 \\
1117\end{array}$ & $\begin{array}{l}661,74 \\
608,29\end{array}$ & 0,134 & Tidak Berbeda \\
\hline $\begin{array}{l}\text { November } \\
\text { Non } \\
\text { November } \\
\end{array}$ & $\begin{array}{l}105 \\
1120 \\
\end{array}$ & $\begin{array}{l}566,19 \\
617,39\end{array}$ & 0,156 & Tidak Berbeda \\
\hline $\begin{array}{l}\text { Desember } \\
\text { Non } \\
\text { Desember }\end{array}$ & $\begin{array}{l}100 \\
1125\end{array}$ & $\begin{array}{l}608,35 \\
613,41\end{array}$ & 0,891 & Tidak Berbeda \\
\hline
\end{tabular}

Sumber: Output SPSS Statistic 25 (2019)

Pada tabel 4 dapat dilihat bahwa implikasi dari penelitian ini menunjukkan bahwa tidak terjadi perbedaan yang signifikan antara rata-rata return bulan Januari dengan bulan non Januari namun terjadi perbedaan yang signifikan antara rata-rata return bulan Februari dengan bulan non Februari di Indeks LQ45 periode 2013-2017.

\section{Rogalsky Effect}

Hasil uji Kruskal Wallis menghasilkan nilai sebagai berikut:
Tabel 5

Hasil Pengujian Kruskal Wallis Rogalsky Effect

\begin{tabular}{|c|c|c|c|c|}
\hline Return & $\mathrm{N}$ & $\begin{array}{l}\text { Mean } \\
\text { Rank }\end{array}$ & $\begin{array}{l}\text { Asym } \\
\text { Sig }\end{array}$ & Keterangan \\
\hline \begin{tabular}{|l|} 
Senin \\
Januari \\
Senin Non \\
Januari
\end{tabular} & $\begin{array}{l}21 \\
223\end{array}$ & $\begin{array}{l}128,12 \\
121,97\end{array}$ & 0,703 & $\begin{array}{l}\text { Tidak } \\
\text { Berbeda }\end{array}$ \\
\hline $\begin{array}{l}\text { Senin } \\
\text { Februari } \\
\text { Senin Non } \\
\text { Februari } \\
\end{array}$ & $\begin{array}{l}20 \\
224 \\
\end{array}$ & $\begin{array}{l}143,78 \\
120,60\end{array}$ & 0,159 & \begin{tabular}{|l} 
Tidak \\
Berbeda
\end{tabular} \\
\hline \begin{tabular}{|l} 
Senin \\
Maret \\
Senin Non \\
Maret
\end{tabular} & $\begin{array}{l}20 \\
224 \\
\end{array}$ & $\begin{array}{l}105,43 \\
124,02\end{array}$ & 0,259 & \begin{tabular}{|l|} 
Tidak \\
Berbeda
\end{tabular} \\
\hline $\begin{array}{l}\text { Senin April } \\
\text { Senin Non } \\
\text { April }\end{array}$ & $\begin{array}{l}18 \\
226\end{array}$ & $\begin{array}{l}105,43 \\
124,02\end{array}$ & 0,259 & $\begin{array}{l}\text { Tidak } \\
\text { Berbeda }\end{array}$ \\
\hline $\begin{array}{l}\text { Senin Mei } \\
\text { Senin Non } \\
\text { Mei }\end{array}$ & $\begin{array}{l}21 \\
223\end{array}$ & $\begin{array}{l}126,24 \\
122,15\end{array}$ & 0,800 & $\begin{array}{l}\text { Tidak } \\
\text { Berbeda }\end{array}$ \\
\hline $\begin{array}{l}\text { Senin Juni } \\
\text { Senin Non } \\
\text { Juni }\end{array}$ & 22 & $\begin{array}{l}94,39 \\
125,29\end{array}$ & 0,050 & $\begin{array}{l}\text { Tidak } \\
\text { Berbeda }\end{array}$ \\
\hline $\begin{array}{l}\text { Senin Juli } \\
\text { Senin Non } \\
\text { Juli }\end{array}$ & $\begin{array}{l}19 \\
225 \\
\end{array}$ & $\begin{array}{l}133,79 \\
121,55\end{array}$ & 0,468 & Berbeda \\
\hline \begin{tabular}{|l|} 
Senin \\
Agustus \\
Senin Non \\
Agustus \\
\end{tabular} & \begin{tabular}{|l|}
20 \\
224 \\
\end{tabular} & $\begin{array}{l}113,79 \\
121,55\end{array}$ & 0,468 & \begin{tabular}{|l} 
Tidak \\
Berbeda
\end{tabular} \\
\hline $\begin{array}{l}\text { Senin } \\
\text { September } \\
\text { Senin Non } \\
\text { September }\end{array}$ & 21 & $\begin{array}{l}129,64 \\
121,83\end{array}$ & 0,628 & \begin{tabular}{|l} 
Tidak \\
Berbeda
\end{tabular} \\
\hline $\begin{array}{l}\text { Senin } \\
\text { Oktober } \\
\text { Senin Non } \\
\text { Oktober }\end{array}$ & \begin{tabular}{|l|}
21 \\
223 \\
\end{tabular} & $\begin{array}{l}160,55 \\
119,92\end{array}$ & 0,010 & Berbeda \\
\hline $\begin{array}{l}\text { Senin } \\
\text { November } \\
\text { Senin Non } \\
\text { November }\end{array}$ & $\begin{array}{l}21 \\
223 \\
\end{array}$ & $\begin{array}{l}104,83 \\
124,16\end{array}$ & 0,230 & $\begin{array}{l}\text { Tidak } \\
\text { Berbeda }\end{array}$ \\
\hline \begin{tabular}{|l} 
Senin \\
Desember \\
Senin Non \\
Desember
\end{tabular} & $\begin{array}{l}20 \\
224 \\
\end{array}$ & $\begin{array}{l}121,03 \\
122,63\end{array}$ & 0,922 & $\begin{array}{l}\text { Tidak } \\
\text { Berbeda }\end{array}$ \\
\hline
\end{tabular}

Sumber: Output SPSS Statistic 25 (2019)

Pada tabel 5 dapat dilihat bahwa implikasi dari penelitian ini menunjukkan bahwa tidak terjadi perbedaan yang signifikan antara rata-rata return hari Senin bulan Januari dengan hari Senin bulan non Januari namun terjadi 
perbedaan yang signifikan antara ratarata return hari Senin bulan Juni dengan hari Senin bulan non Juni dan hari Senin bulan Oktober dengan hari Senin non bulan Oktober di Indeks LQ45 periode 2013-2017.

\section{Week Four Effect}

Hasil uji Kruskal Wallis menghasilkan nilai sebagai berikut:

Tabel 6

Tabel Hasil Pengujian Kruskall Wallis Week-Four Effect

\begin{tabular}{|c|c|c|c|c|}
\hline Return & $\mathrm{N}$ & $\begin{array}{l}\text { Mean } \\
\text { Rank }\end{array}$ & $\begin{array}{l}\text { Asym } \\
\text { Sig }\end{array}$ & $\begin{array}{l}\text { Keteran } \\
\text { gan }\end{array}$ \\
\hline $\begin{array}{l}\text { Senin } \\
\text { Akhir } \\
\text { Bulan }\end{array}$ & 76 & 113,17 & 0,165 & $\begin{array}{l}\text { Tidak } \\
\text { Berbeda }\end{array}$ \\
\hline $\begin{array}{l}\text { Senin } \\
\text { Awal } \\
\text { Bulan }\end{array}$ & 168 & 126,72 & & \\
\hline
\end{tabular}

Sumber: Output SPSS Statistic 25 (2019)

Pada hasil pengujian diatas dapat dilihat bahwa tidak terjadi perbedaan, hal ini dapat dilihat dari hasil pengujian dengan nilai Asymp Sig. yang bernilai 0,165 yang lebih besar jika dibandingkan dengan 0,05. Maka, dapat disimpulkan bahwa tidak ditemukan anomali WeekFour Effect pada saham yang terdafdar dalam indeks LQ45 periode 2013-2017

\section{Pembahasan The Day of The Week Effect}

Dapat kita lihat pada tabel 3 bahwa terjadi perbedaan yang signifikan pada return hari Rabu dengan hari non Rabu. Hal ini dapat dilihat dari nilai Asymp. Sig. yang bernilai lebih kecil dari 0,05.

Fenomena The Day of The Week Effect yang terjadi pada hari Rabu ini dapat disebabkan oleh tindakan investor yang melakukan transaksi jual beli saham setelah memperoleh informasi-informasi yang mereka dapatkan dan kemudian menyusun strategi. Investor menggunakan awal minggu untuk melakukan kajian terkait informasi yang mereka miliki sehingga investor akan mulai melakukan transaksi jual beli saham setelahnya. Tindakan profit taking yang dilakukan investor dalam menghadapi akhir pekan dan hari libur dapat berimplikasi terhadap tingkat return yang positif pada hari Rabu. Investor menggunakan informasi yang dianggap baik yang masuk ke pasar pada awal pekan sebagai bahan dalam pertimbangan untuk membeli saham pada hari Rabu.

\section{Pembahasan January Effect}

Pada tabel 4 dapat kita lihat bahwa Asymp. Sig bulan Januari memiliki nilai sebesar 0,352. Dari nilai Asymp. Sig dapat kita simpulkan bahwa tidak terjadi anomali January Effect pada saham yang terdaftar secara konsisten di Indeks LQ45 periode 2013-2017 karena nilai Asym. Sig $>$ 0,05. Namun, hasil penelitian menunjukkan bahwa terjadi perbedaan rata-rata return yang terjadi pada bulan Februari dengan rata-rata return bulan non Februari dimana rata-rata return pada bulan Februari lebih tinggi dibandingkan dengan rata-rata return bulan non Februari. Hal ini ditunjukkan dengan nilai Asymp. Sig bulan Februari dengan nilai 0,042 yang lebih rendah dari 0,05 dengan nilai mean rank bulan Februari lebih besar dari bulan non Februari.

Hasil penelitian menunjukkan bahwa pada Indeks saham LQ45 tidak terjadi perbedaan return saham pada bulan Januari dengan bulan non Januari tahun 2013 - 2017. Budaya Indonesia berbeda negara-negara lainnya. Negaranegara lainnya memiliki beberapa perayaan akhir tahun seperti hari raya natal dan tahun baru dimana mayoritas penduduk negara tersebut akan merayakan hari raya tersebut dengan besar-besaran sehingga perayaan membutuhkan dana yang terbilang cukup besar. Dalam menghadapi hari raya ini, investor akan lebih cenderung untuk menahan investasinya agar mereka dapat memenuhi kebutuhan mereka dalam melaksanakan hari raya natal dan tahun baru. 
Implikasi dari penelitian ini menunjukkan bahwa adanya perbedaan rata-rata return antara rata-rata return pada bulan Februari dengan bulan non Februari. Penelitian ini menggunakan 29 sampel perusahaan yang sebagian besar dari sampel merupakan perusahaan yang bergerak di sektor properti. Rata-rata return pada bulan Februari setiap tahunnya lebih tinggi jika dibandingkan dengan rata-rata pada bulan-bulan lainnya. Hal ini disebabkan karena adanya penurunan tingkat suku bunga acuan Bank Indonesia pada setiap bulan Februari yang memicu terjadinya penurunan tingkat suku bunga kredit. Dengan turunnya tingkat suku bunga kredit, masyarakat akan cenderung untuk melakukan kredit untuk melakukan investasi dalam bentuk properti yang akan berdampak pada naiknya penjualan pada perusahaan sektor porperti. Informasi ini dapat memicu investor dalam melakukan aksi beli saham perusahaan sektor properti yang kemudian akan berdampak pada naiknya harga dan return saham perusahan properti pada bulan Februari.

\section{Pembahasan Rogalsky Effect}

Pada hasil penelitian yang tertera pada tabel 5 menunjukkan bahwa tidak terjadi Rogalsky Effect pada saham yang terdaftar dalam Indeks LQ45 periode 2013 sampai dengan 2017 . Jika kita lihat pada tabel 5 , benar bahwa nilai return rata-rata pada hari Senin di bulan Januari lebih besar dibandingkan dengan return rata-rata pada hari Senin non bulan Januari. Namun, perbedaan ini dinilai tidak signifikan karena hasil pengujian menyatakan nilai Asymp. Sig > 0,05.

Pada tabel 2 dijelaskan bahwa tidak terjadi perbedaan pada bulan April karena nilai dari Asymp. Sig. lebih besar dari 0,05 . Hal ini menunjukkan bahwa fenomena Rogalsky Effect pada bulan April tidak terjadi. Hal ini terjadi karena adanya aturan di Indonesia yang membahas tentang karakteristik kualitatif keuangan yang menjadi standar dalam penyusunan laporan keuangan yaitu
PSAK (Pernyataan Standar Akuntansi Keuangan) No. 1. PSAK No. 1 Tahun 2017 ini membahas tentang penyajian laporan keuangan. Aturan dari PSAK No. 1 ini lah yang akhirnya dapat meminimalisir adanya informasi yang asimetris yang berimplikasi pada tidak adanya pengaruh dari penerbitan laporan keuangan terhadap harga serta return saham.

Dapat kita lihat pada tabel 5 terdapat implikasi dari penelitian yang menunjukkan bahwa terdapat perbedaan rata-rata return pada hari Senin bulan Juni dengan rata-rata return hari Senin non bulan Juni dan rata-rata return hari Senin bulan Oktober dengan rata-rata return hari Senin bulan Oktober. Dilihat dari nilai mean ranks, mean ranks hari Senin bulan Juni lebih kecil dibanding mean ranks hari Senin non bulan Juni. Ini menunjukkan bahwa rata-rata return hari Senin bulan Juni lebih kecil dibandingkan dengan rata-rata return hari Senin bulan non Juni. Sedangkan untuk bulan oktober, rata-rata return hari Senin bulan Oktober lebih besar dibandingkan dengan rata-rata return hari Senin bulan non Oktober.

Perbedaan yang terjadi di bulan Juni ini terjadi karena banyaknya karena terdapat banyak hari libur yang terjadi pada hari-hari menjelang akhir pekan. Libur pada akhir pekan yang panjang ini mendorong investor untuk melakukan aksi jual untuk mengantisipasi perubahan informasi selama libur akhir pekan yang panjang. Contohnya seperti yang terjadi pada hari Kamis tanggal 6 Juni 2013 terjadi perayaan Isra Miraj yang kemudian hari Jumat sering disebut dengan hari kejepit dimana pada hari kejepit, kebanyakan orang malas kembali berkativitas kantoran sehingga mereka lebih memilih untuk cuti. Saat memasuki hari Senin, investor memerlukan waktu yang lebih panjang untuk menyerap informasi yang tersebar di pasar modal sehingga rata-rata return hari Senin di bulan Juni lebih rendah dibandingkan rata-rata retun hari Senin pada bulan non Juni. 
Implikasi lain yang terjadi pada bulan oktober terjadi karena besarnya pengaruh psikologis yang menunjukkan besarnya keinginan investor untuk melakukan transaksi pada hari Senin dibandingkan dengan hari lainnya pada bulan Oktober. Hal ini dikarenakan adanya informasi yang menyenangkan (Favorable Information) pada hari Jumat. Besarnya keinginan investor dalam melakukan transaksi pada hari Senin dapat dibuktikan dengan besarnya volume transaksi di hari Senin pada bulan Oktober.

\section{Pembahasan Week-Four Effect}

Berdasarkan hasil pengujian yang telah dilakukan, tidak terdapat perbedaan yang signifikan antara ratta-rata return hari Senin akhir bulan disbanding ratarata return hari Senin awal bulan pada saham yang terdaftar dalam Indeks LQ45 periode 2013-2017. Hasil ini dapat dilihat pada nilai Asymp. Sig pada tabel 6 yang menunjukkan angka 0,165 > 0,05 yang berarti $\mathrm{H}_{0}$ diterima atau tidak terjadi perbedaan yang signifikan.

Tidak terjadinya Week-Four Effect pada saham yang terdaftar dalam indeks LQ45 periode 2013-2017 terjadi karena investor sudah tidak menggunakan dana operasional dalam melakukan tindakan investasi pada pasar modal. Saat ini investor telah membagi dana mereka menjadi dua yaitu dana alokasi untuk investasi dan dana untuk operasional. Hal ini berimplikasi pada suatu keadaaan ketika investor membutuhkan dana secara operasional mereka tidak perlu lagi menjual sahamnya untuk mendapatkan dana. Hal ini lah yang menjelaskan bahwa saat akhir bulan dan investor dituntut untuk membuhi kebutuhan hidupnya, dana yang digunakan untuk memenuhi kebutuhan hidup serta membayar tagihan tidak berasal dari dana yang mereka gunakan dalam investasi. Hasilnya, tidak akan terjadi perbedaan penawaran dan penjualan pada akhir dan awal bulan yang berimplikasi pada harga dan return saham.

\section{KESIMPULAN}

Berdasarkan pengujian analisis statistik deskriptif menunjukkan bahwa nilai tertinggi rata-rata return terjadi pada hari Rabu dengan nilai 0,12584 dan terendah pada hari Kamis dengan nilai 0,007208 . Kemudian seluruh dari nilai dari rata-rata return menunjukkan nilai yang lebih kecil disbanding standar deviasi yang berarti data cenderung tidak berkelompok.

Terjadi anomali The Day of The Week Effect pada saham yang terdaftar dalam indeks LQ45 periode 2013-2017. Anomali The Day of The Week Effect yang ditemukan terjadi pada hari Rabu. Hal ini menunjukkan bahwa return saham hari Rabu berbeda dengan return saham hari-hari lainnya secara signifikan pada periode 2013-2017.

Tidak terjadi anomaly January Effect pada saham yang terdaftar dalam indeks LQ45 periode 2013-2017. Hal ini menunjukkan bahwa return bulan Januari tidak berbeda dengan return bulan-bulan lainnya secara signifikan pada periode 2013-2017.

Tidak terjadi anomaly Rogalsky Effect pada saham yang terdaftar dalam indeks LQ45 periode 2013-2017. Hal ini menunjukkan bahwa return hari Senin bulan Januari dan return hari Senin bulan April tidak berbeda dengan return hari Senin pada bulan-bulan lainnya secara signifikan pada periode 2013-2017.

Tidak terjadi anomaly Week-Four Effect pada saham yang terdaftar dalam indeks LQ45 periode 2013-2017. Hal ini menunjukkan bahwa return hari Senin akhir bulan tidak berbeda dengan return hari Senin awal bulan secara signifikan pada periode 2013-2017.

\section{IMPLIKASI DAN KETERBATASAN}

Implikasi temuan dari penelitian ini adalah ditemukannya perbedaan return pada bulan Februari dengan bulan non Februari, Hari Senin bulan Juni dengan hari Senin bulan non Juni, dan Hari Senin bulan Oktober dengan hari Senin bulan non Oktober. 
Penelitian ini terbatas pada perusahaan yang terdaftar pada Indeks LQ45 saja. Kemudian anomali yang diteliti hanya meneliti anomali-anomali yang tergolong dalam anomali musiman (Seasonal Anomaly) sehingga penelitian ini maish sangat mungkin untuk dikembangkan mengingat masih banyak anomali yang masih dapat diteliti.

Saran yang dianjurkan peneliti adalah bagi akademisi agar dapat menjadi referensi dalam melakukan penelitian mengenai return saham dan juga bisa sebagai alat penambah wawasan. Bagi peneliti selanjutnya diharapkan dapat mengganti objek penelitian pada indeks lain yang ada di Indonesia misalnya IHSG, IDX30, JII, atau indeks lainnya dan diharapkan peneliti selanjutnya dapat menambah anomali yang diteliti tidak hanya anomali musiman melainkan anomali peristiwa, perusahaan, dan akuntansi. Sementara untuk investor, dengan ditemukannya anomali The Day of The Week Effect dalam penelitian ini maka peneliti menyarankan agar investor yang hendak melakukan investasi pada saham yang terdaftar dalam indeks LQ45 untuk memperhatikan anomali The Day of The Week Effect yang terjadi pada hari Rabu guna memperoleh return yang optimum.

\section{REFERENCES}

\section{Cahyaningdyah, D. (2017). Analisis Pengaruh Hari Perdagangan Terhadap Return Saham di Bursa Efek Indonesia: Pengujian Menggunakan GARCH(Generalized Conditional Heteroskedasticity). Jurnal Manajemen dan Bisnis.}

Cahyaningdyah, D. (2017). Analisis Pengaruh Hari Perdagangan Terhadap Return Saham di Bursa Efek Indonesia: Pengujian Menggunakan GARCH(Generalized Autoregressive Conditional
Heteroskedasticity). Jurnal Manajemen dan Bisnis.

Damodaran, A. (1996). Investmen Valuation: University Edition, . Inc: John Wiley and Son.

Fahmi, I. (2014). Pengantar Manajemen Keuangan. Bandung: Alfabeta.

Indrasari, A., \& Tahar, A. (2016). Analisis Pengaruh Day of The Week Effect terhadap Return Saham di Bursa Efek Jakarta. Jurnal Akuntansi dan Investasi.

Jones, C. P. (2014). Investments Analysis and Management. Twelfth Edition. Singapore: John Wiley \& Sons Singapore Pte, Ltd.

Putra, P. E. (2016). Efek Awal dan Akhir Pekan Terhadap Tingkat Pengembalian Saham di Bursa Efek Indonesia. Malang: Universitas Muhammadiyah Malang.

Rita, M. R. (2009). Pengaruh Haril Perdagangan Terhadap Return Saham: Pengujian Day of the Week Effect, Week-Four Effect dan Rogalski Effect di BEI. Jurnal Ekonomi dan Bisnis.

www.iaiglobal.or.id 